\title{
Neo-hydraulic water management: an international comparison of idle desalination plants.
}

\begin{abstract}
Desalination has been proposed as a solution to water scarcity. However, it is a highly energy intensive and expensive water treatment method, and many new desalination plants remain idle for extended periods. This paper uses qualitative comparative analysis to analyse four cases of idle plants: the Charles E. Meyer Desalination Plant (Santa Barbara, USA), the Kurnell Desalination Plant (Sydney, Australia), the Torrevieja Desalination Plant (Alicante, Spain), and the Thames Gateway Water Treatment Works (London, England). It develops the original concept of neo-hydraulic water management. Neo-hydraulic water management refers to the persistence of capital-intensive, supply-side solutions in response to uncertainty. The increasing role of private capital and the emphasis on treatment technologies, signal new elements of the neo-hydraulic approach as depicted. This paper is significant in its attention to excess desalination capacity, explained by the emergence of neo-hydraulic water management despite global efforts to improve sustainability and integration.
\end{abstract}




\section{Introduction}

In recent decades, water management discourse and policy have emphasized the need for integration and sustainability. This is often discussed in terms of paradigms of water management, emphasizing an emerging shift from the 'hydraulic paradigm' of the twentieth century characterized by large-scale, centralized, supplyside hydraulic infrastructure to a new paradigm of 'sustainable and resilience urban water management' based on environmental protection, demand management, decentralized technologies, adaptation to climate change and water sensitive design.

Desalination sits uneasily within this new paradigm of water management. For proponents, it promises to be one of the most significant technological breakthroughs in the modern era (Hashim and Hajjaj, 2005). On a planet with less than $0.01 \%$ of all water suitable and available for human use, a growing population and changing climate, desalination offers the potential for limitless, climate-independent supply of freshwater by making saltwater drinkable (Shiklomanov, 1993). Desalination seems to be the ultimate technical solution to water scarcity, one of the most alarming resource and environmental constraints on human development and economic growth. Despite the optimism, desalination is not without its limits and critics. The capital and operating costs of desalination plants have decreased and the energy efficiency has increased significantly in recent decades, but the technology remains highly energy intensive and expensive compared to conventional water resources. For large-scale desalination projects, electricity accounts for between $20 \%$ and $35 \%$ of the total project costs (Wilf et al., 2007), and the high energy consumption negatively impacts the environment through greenhouse gas emissions where electricity is produced using fossil fuels (Younos, 2005). Desalination intakes can entrain marine life and disturb local flow patterns, and the discharge of the extremely salty brine waste also has impacts on temperature and chemistry of receiving environments (Hoepner, 1999; Lattemann and Höpner, 2008; Miller et al., 2015; Palomar and Losada, 2010; Danoun, 2007; Hashim and Hajjaj, 2005).

Desalination proponents have emphasized its role in urban water sustainability and resilience including its benefits compared to regional water transfers, the potential for renewable energy and system design to reduce environmental impacts, and its role in 'drought-proofing' cities. However, as an expensive, 
centralized, supply-side option for water management, desalination also re-enforces many of the elements of the old hydraulic paradigm.

Idle desalination plants are particularly prescient as exemplars of the strength of technology and capital intensive responses to the challenge of water security, despite expectations of a transition to integrated, sustainable water management. Several high-profile, award-winning desalination plants constructed since 2000 have never operated at full-capacity, while others are underutilized. Desalination plants typically remain idle due to high operating costs, resulting from high energy requirements. Plants constructed as a response to drought have become redundant with the return to normal rainfall patterns. The global extent of underutilization of desalination capacity is difficult to establish as industry data sources report installed capacity, rather than operational output.

This paper develops the concept of 'neo-hydraulic water management' to account for the persistence of core elements of supply-side, centralized responses to urban water management amidst efforts towards sustainable and integrated urban water management. The neo-hydraulic approach has emerged in the context of privatization and financialization in the water sector, re-enforcing reductionist framings of water security which run counter to calls for integration that are part of emerging water management paradigms. The aim of this paper is to analyze case studies of idle desalination plants in order to identify the key elements of the neo-hydraulic approach. Idle desalination plants are particularly instructive case studies as they demonstrate the strength of supply-side approaches to water management within wider efforts to achieve a transition to a sustainable and integrated water management paradigm.

The paper uses a comparative case study method. Qualitative analysis of technical and policy documents, media reports, and previous studies relating to hydrological, political, ecological and economic factors is applied to four idle desalination plants: Santa Barbara (California, USA), Sydney (New South Wales, Australia), Torrevieja (Alicante, Spain) and London (England, UK). The case studies are selected to enable analysis of the phenomena of idle plants in developed economies, with different water governance and political systems, and diverse hydrological and environmental contexts. The selected case study plants were intended to produce water for municipal supply, with Torrevieja also supplying agriculture. The comparative 
method aims to identify similarities that may be attributed to global trends in the sector, as they are experienced in specific local contexts. Multiple data sources are used to provide validity of data presented within each case study, and to cover the different elements of interest for analysis. Comparison and discussion of the cases show the vulnerability of integrative water security strategies to expensive technological solutions, undermining wider movements towards sustainability and enforcing a neo-hydraulic framing of water management.

\section{Desalination}

After a decade of rapid growth, global demand for new desalination slowed after the 2008 financial crisis. (IDA 2016). Contracts for new desalination plants peaked in 2007 at more than 7 million cubic meters per day $\left(\mathrm{Mm}^{3} /\right.$ day), and in 2015 new contracted capacity was less than half that at $3.2 \mathrm{Mm}^{3} /$ day. In 2007 installed global desalination capacity was $48 \mathrm{Mm}^{3} /$ day, and by 2013 , total global capacity was over 80 $\mathrm{Mm}^{3} / \mathrm{day}$, an average growth rate of installed capacity of more than 9\% per year (Bennett, 2015; IDA, 2008; Roberts et al., 2010). In 2018 total global installed capacity was $95 \mathrm{Mm}^{3} /$ day, showing growth slowing to $3.5 \%$ per year on average in the preceding five years (IDA, 2015; Jones et al., 2019. In China, one of the markets forecast for strongest growth, desalination capacity increased from $0.01 \mathrm{Mm}^{3} / \mathrm{day}$ in 2000 to 0.7 $\mathrm{Mm}^{3} /$ day in 2011, yet by 2015 it had achieved less than half the government target of 2.2-2.6 $\mathrm{Mm}^{3} /$ day, with total installed capacity of $1.03 \mathrm{Mm}^{3} /$ day (Chye, 2013; Sun, 2016; Zheng et al., 2014).

Evidence is emerging that desalination plants installed during the recent boom are underutilized. Despite significant capital investment, high-profile, award winning facilities have never been used. Desalination plants are generally designed to operate at $90 \%$ of their maximum capacity (Troy, 2011; Wilf et al., 2007). In 2016 the pilot phase of the flagship Chinese Bohai Bay desalination plant, intended to supply up to one third of domestic water supply to Beijing by 2019 , was operating at less than $10 \%$ of capacity, supplying up to $5,000 \mathrm{~m}^{3} /$ day to a coal fired power plant (Sun, 2016). In Australia, desalination plants were installed in five major cities during the 'Millennium Drought' of 1998-2010, but only Perth has used desalination for baseflow water supply beyond the testing period after construction (Turner et al., 2016). The Gold Coast plant has been used as emergency supply after severe flooding in 2011, 2013 and 2017, and in Melbourne water from the desalination plant was ordered for the first time in 2016 in the midst of financial and political 
controversy, despite dams being more than 60\% full (SEQ Water, 2018; ABC, 2017). In 2012 only $16 \%$ of Spain's installed desalination capacity was being utilized (March, 2015).

Global desalination capacity is still growing, but the rate of growth has slowed and under-utilization of plants already installed raises concerns about 'stranded assets' and the implications for the cost of water to consumers and governments. The recent slowdown and overcapacity in some cities may be due to short-term political, environmental and economic uncertainties, but is also indicative of limits to the technologically optimistic representation of desalination as the ultimate foundation for modern water security.

\section{Paradigms of water management}

Integration of water management has been explicitly recognized in international statements and agreements related to sustainable development since the early 1990s, though the idea of integration can be traced back to the middle of the twentieth century (Biswas, 2004). Chapter 18 of the 1992 United Nations Conference on Environment and Development resolution, known as Agenda 21, addressed 'Protection of the Quality and Supply of Freshwater Resources: Application of Integrated Approaches to the Development, Management and Use of Freshwater Resources' (United Nations Sustainable Development, 1992, p. 21). Agenda 21 set the basis for integration of water management, outlining an approach that integrates supply, demand, sanitation, drainage and flood protection, and is based on full public participation in water management policy and decision making. Sustainable Development Goal 6 includes the target 'By 2030, implement integrated water resources management at all levels, including through transboundary cooperation as appropriate' (United Nations Department for Economic and Social Affairs, 2018).

Integrated Urban Water Management (IUWM) translates this approach to the city scale. The emphasis is on managing water supply, wastewater treatment, drainage and flood control to achieve mutual benefits and sustainable development (Bahkri, 2012; Brown et al., 2009; Mitchell, 2006). Following the principles of stakeholder engagement and public participation, IUWM involves different sections of water and wastewater utilities, local government, planners, developers, industry and civil society, bridging urbanization processes and water management. IUWM aims to improve the efficiency of water use, identify opportunities for reducing reliance on external resources, and minimize the volume of water to be transferred and treated in 
wastewater and stormwater systems. IUWM literature speaks of the need to understand cities as water catchments and to move from single use, linear flows to circular patterns which reuse water within the city rather than disposing of wastewater and surface water into the environment (Andrew, 2007; Bahkri, 2012).

The move towards sustainable and integrated management of water has been presented as the latest in a series of paradigms or stages of development. Brown et al. (2009) analyze the history of urban water management in Australian cities and identify six regimes beginning with early European settlement and projecting into the future. The regimes are the water supply city, the sewered city, the drained city, the waterways city, the water cycle city and the water sensitive city. Current and future research and development are focused on moving towards the water cycle city and water sensitive city, with limited evidence that these are being achieved yet. Novotny et al (2010) also take a historical view of the development of urban water systems, identifying four historical paradigms from ancient times to the modern era. The historical paradigms of urban water management are: basic water supply; engineered water supply and runoff conveyance; fast conveyance with no treatment; and fast conveyance with end of pipe treatment. They also outline an emerging fifth paradigm of sustainability which will lead to the creation of watercentric ecocities. Fletcher et al. (2014) review the evolution of terminology associated with urban drainage, with a proliferation of different terms used in different contexts since the 1980s providing evidence of a transition towards more sustainable and integrated approaches.

Tony Allan (2005) describes five paradigms of water management: premodern; industrial modernity; green; economic; and political and institutional. The final paradigm emphasizes integrated water resources allocation and management, while each of the preceding paradigms emphasize particular elements of the water economy, society and environment. According to Allan, a key turning point in water management occurred in the 1980s, as a shift from the 'hydraulic mission' of industrial modernity to the reflexive modernity of the later paradigms. Reflexive modernity has been associated with greater emphasis on 'uncertainty' in water management, compared to the 'certainty' of the industrial hydraulic mission, which was associated with construction of large engineering structures and distribution systems to ensure reliable water supply for economic development. 
In his history of water, environment and development Donald Worster (1985) describes the American West as a 'modern hydraulic society... a social order based on the intensive, large-scale manipulation of water and its products in an arid setting' (p. 7). He traces the role of state-led, capitalist development of large dams and water distribution infrastructure as the basis for settlement, agriculture, industrialization and capital accumulation, all requiring the domination of rivers, the conquest of the arid landscape and the disenfranchisement of small landholders and indigenous peoples. Norris Hundley's (1992) history of water in California addresses similar themes to Worster, with greater attention to the development of cities such as Los Angeles. He also uses 'hydraulic society' to describe the development of capital intensive water infrastructure as the basis for California's success, highlighting challenges to this mode of development since the 1960s. Environmental harm, legal challenges to water rights and the changing role of agriculture in the economy and society at the end of the twentieth century disrupted the established structures of the hydraulic society, requiring reform of the politics and institutions of water management.

In Spain, Saurí and Moral (2001) write of similar patterns of development, characterized as the 'hydraulic paradigm', 'with the ultimate objective of ensuring cheap water availability for economic growth' (p.351). A key feature of the hydraulic paradigm is 'the continuous expansion of the urban water ecological footprint through the construction of new water ('hydraulic') works for the augmentation of supplies' (Kallis and Coccossis, 2002, p.245). For March et al. (2014), desalination represents the 'most recent mutation' of the hydraulic paradigm in Spain, with its emphasis on centralized planning of technological solutions to problems of water scarcity.

Water security has become a prominent framing of water management and infrastructure debates and discussions since the 2000s, moving beyond calls for integrated water resources management (Cook and Bakker, 2012). Zeitoun et al. (2016) identify two distinct framings of water security - reductionist and integrative. Reductionist water security focusses on quantitative modelling of water resources, demand and risk, and leads to technology and infrastructure focused solutions, in line with the certainty of Allan's hydraulic mission. Integrative approaches to water security by contrast address wider concerns about equity of access to water, distribution of costs and benefits and the need for strong institutions and governance. While integrative approaches to water scarcity might draw attention to institutional and social factors, 
reductionist approaches to water security are more compatible with the hydraulic paradigm, providing further grounds for capital intensive approaches to mitigate uncertainty in water resources. Desalination as a response to falling dam levels can be seen in reductionist terms, providing a certain volume of water based on the rated capacity of the installation, which can be called upon to alleviate uncertainty about rainfall and demand.

The hydraulic paradigm was largely based on state investment in infrastructure for agricultural and urban development during the nineteenth and twentieth centuries. Since the 1980 s the private sector has been increasingly involved in delivering water infrastructure and services (Bakker, 2010). Water infrastructure in stable capitalist democracies has become an attractive investment for financial institutions, providing opportunities to secure capital assets with consistent, regulated returns. Loftus and March (2016) show the influence of global capital investment on decisions to implement desalination in London and Spain. The financialization of the water sector refers to the reframing of infrastructure as an investment instrument and capital asset, rather than a primarily public health service or state enabler of economic growth (Loftus and March, 2016). Private capital investors, technology providers, engineering firms and contractors are direct beneficiaries of decisions to implement desalination or other large infrastructure, funded by water bill payers and governments.

This paper distinguishes 'neo-hydraulic' approaches to water management from the hydraulic paradigm, for the first time. This is to emphasize the role of private finance and the shift from large, classical hydraulic structures of dams and pipelines, to new an emphasis on new technologies to treat water of any quality to drinking standard. Whilst the global water management community heralds the emergence of the latest paradigm of integrative, sustainable water management, it is evident that this transformation is far from complete. The hydraulic paradigm of state-led construction of large infrastructure may be receding but key features of this approach remain prominent in political discourse and decision-making. The emphasis on certainty of supply and reliance on capital-intensive engineering-led solutions can be characterized as the neo-hydraulic paradigm. State funding has been replaced by the financialization of the sector, as private capital seeks secure returns on investment, and damming of major rivers is now less common than the construction of high-tech membrane water treatment and reclamation facilities. Reductionist approaches to 
water security draw attention to technological, engineering solutions to provide high certainty of supply, despite efforts of integrative approaches to emphasize institutional, economic and social reform. Water remains a natural resource to be abstracted, treated and distributed for social and economic development in the face of an uncertain climate, in contrast to the sustainability principles that are intended to underpin the integrated water management paradigm of the twenty-first century.

Whilst this may partly be explained through the lens of financialization and the powerful interests of capital, it also demonstrates the stability and durability of socio-technical and institutional systems that have evolved to provide safe water to cities (Bell, 2018). Neo-hydraulic approaches to water management require minimal intervention in urban life and politics, providing a relatively simple technological solution to the problem of water scarcity, compared to the deeper reforms required to achieve integrated, sustainable urban water management. Water infrastructure, policies and professions that have evolved with the hydraulic paradigm of engineering-led expansion of water supply are therefore likely to find consistency and stability in desalination as a certain source of water in the midst of the uncertainty of drought, even if it comes at great expense and is under-utilized in operation. The four cases of idle desalination plants described in this paper demonstrate neo-hydraulic water management as a response to drought and the possibility of future water scarcity, in the midst of transitions to a sustainable, integrated water management paradigm.

\section{California: The Santa Barbara Desalination Plant}

The Charles E. Meyer desalination plant in Santa Barbara commenced construction in 1991 in response to a severe drought between 1987-1992. This drought resulted in strong support from the local population for the construction of the desalination plant and a pipeline to connect it to the centralized state water project (Cooley et al., 2006). The facility cost US\$34 million and had a potable water capacity of 25 million liters per day (ML/d) (IDE, 2015). At 2015 prices, the capital cost was US\$2.37/ML/day (IDE, 2015). The cost of the project was transferred to consumers through increased water prices, which further depressed water demand, already reduced as a result of water conservation campaigns (Cooley et al., 2006). The plant was completed in March 1992 which was also the year in which the drought ended (Cooley and Ajami, 2012). Reduced water demand coupled with increased rainfall meant that the plant was used only for a five month testing period and was inactive for more than 25 years after it was completed (Hamilton, 2015). The plant 
officially went into long-term standby mode in 1997 and its RO membranes were sold for use in the Middle East (Cooley and Ajami, 2012).

In July 2015, as the 25-year lifespan of the original plant came to an end, Santa Barbara City Council approved a US\$55 million reactivation program for a 10ML/day plant in response to what was reported as one of the most extreme droughts in California's history (Hamilton, 2015). The original plant was designed, financed, built and operated by American company Ionics, Inc. (now part of GE). A partnership between the City of Santa Barbara and two local water agencies, which both later departed from the project, repurchased the plant from Ionics over a five-year period (Cooley and Ajami, 2012). IDE Americas, a subsidiary of Israeli desalination company IDE Technologies, was contracted to design, build and operate the reactivated plant which will produce $10(\mathrm{ML} / \mathrm{d})$ of potable water, serving around $30 \%$ of the city's annual water demands (IDE, 2015).

The original reactivation project cost, announced in March 2015, was expected to be significantly lower than final cost, at US\$40 million instead of US\$72 million (Water Resources Division, Public Works Department, 2015; City of Santa Barbara, 2019). The high cost of the reactivation program is partially a reflection of how quickly desalination practices change. Within the last 25 years, significant progress has been made in the understanding of the environmental impact of desalination (Lattemann and Höpner, 2008). For example, California has introduced new criteria for subsurface intakes and diffusers to prevent a column of brine forming off the coast (Gasson, 2015). The original plant intake structures did not meet current standards of environmental safety and have been upgraded as part of the planned reactivation, leading to additional capital and operating costs.

\section{Australia: The Kurnell (Sydney) Desalination Plant}

The Kurnell desalination plant was constructed between 2007 and 2010 to provide potable water to Sydney and the surrounding area south of Sydney Harbour (Who We Supply, 2016). The plant can produce 250 ML/d of desalinated water, meaning it is able to supply $15 \%$ of Sydney's water needs, and this can be increased to $500 \mathrm{ML} / \mathrm{d}$ if required (IPART, June 2011). It was planned in response to what is now known as the 'millennium drought', a widespread drought which began in 2000 (Radcliffe, 2015). 
Desalination was included within a framework of 'real options' water resources planning in New South Wales in the early years of the drought. The plan was based on a 'least cost' analysis, which provided a sequence of actions to be implemented at pre-determined trigger points based on dam levels (Turner et al., 2016). It included desalination 'readiness to construct', which involved letting contracts to allow for preapproval and design of a desalination plant ahead of a final decision to go ahead. This was intended to avoid delays to construction should desalination be needed, but also to avoid prematurely investing in desalination should the drought break (Turner et al., 2016).

Turner et al. (2016) provide a useful account of the decision to proceed with desalination in Sydney. In 2006 the Sydney Metropolitan Water Plan review adopted a policy to start construction of desalination if dam levels fell to $30 \%$ of capacity. However, in 2007 , with dams at $34 \%$ and falling at a rate of $0.5 \%$ per week the decision was taken to start construction. This was immediately before the start of the 'caretaker' period of government during the 2007 state election campaign. There was concern that dam levels could reach $30 \%$ during the campaign, when it would be inappropriate for the government to take decisions on major infrastructure projects. Soon after the decision to proceed, Sydney received significant rainfall. Dam levels never reached the $30 \%$ trigger, and by the time the contract was signed in 2008 dams were $55 \%$ full.

The Kurnell desalination plant is owned by Sydney Water, a NSW government-owned corporation, was constructed by Blue Water (a joint venture between John Holland and Veolia Water), and is operated by Veolia Water (Fuenfschilling and Truffer, 2016). Since 2012 it has been leased jointly to the Ontario Teachers’ Pension Plan Board and Hastings Funds Management Ltd.

The Sydney area began to move out of drought in 2008, just one year into plant construction (AAP, 2008). Despite becoming clear that the facility would not be used to relieve water shortages, the plant was named "Desalination Plant of the Year" at the 2011 Global Water Summit ("Kurnell Desalination Plant", 2016). When construction was completed, the desalination plant was run for a testing period until 2012 to prove its capacity and reliability. By June 2012 dam levels were almost at maximum capacity, resulting in the plant being deactivated in July 2012 and remained idle until 2019 (Trembath, 2015; Cockburn, 2019). Reactivation 
began in January 2019 when dam levels reached 60\% full, before water use restrictions were put in place, and will be returned to stand-by if dam levels return to 70\% (Sydney Desal, 2018). The reactivation program takes eight months.

The plant was predicted to increase the electricity demand in New South Wales by $1.2 \%$ if upgraded to a 500 (ML/d) capacity project (Lattemann et al., 2010). The Kurnell desalination plant receives energy from the region's electricity grid, which is fully offset by a 67 turbine wind farm constructed as part of the project (Miller et al., 2015).

Desalination plants are a key reason why water prices in all Australian states are rising, despite most desalination plants in the country lying idle (Dillon, 2011). During the millennial drought the principal concern of the Australian public relating to desalination was cost (Dolnicar and Hurlimann, 2010). In 2007, when the construction of the Sydney plant was announced, it was estimated that desalinated water produced in a carbon neutral way would have to be sold at three times the 2007 water cost (Dickie, 2007). Current water prices are set by the Independent Pricing and Regulatory Tribunal (IPART) and increase with the length of the shutdown period (IPART, December 2011). The plant cost A $\$ 1.9$ billion (US $\$ 1.4$ billion) to construct (Kurnell Desalination Plant, 2016) and by 2015 was estimated to have cost A\$534 million (US\$385 million) during its three years of being idle, highlighting the expense of maintaining desalination technology even when it is inactive (Trembath, 2015). Furthermore, the Intergovernmental Agreement on the National Water Initiative (2004), which sets out a national framework for Australian water management, includes a commitment to full cost recovery, including debt servicing, with which the NSW government must comply (Radcliffe, 2015), so that the cost of the desalination plant must be borne by Sydney Water customers. Sydney Water customers' bill are expected to increase by around US\$20 per year while it is operational, in addition to the US\$63 increase in annual bills since it was first commissioned to cover the base costs of the plant (Sydney Desal, 2014; Cockburn, 2019).

\section{Spain: The Torrevieja Desalination Plant}

Although Europe's combined desalination capacity only accounts for $14 \%$ of all global desalination, Spain on its own accounts for $8 \%$ of world desalination capacity (Lattemann et al., 2010). The country is a world 
leader in desalination, with its first plants constructed in the Canary Islands in the 1960s. Today, 65\% of Spain's total desalination capacity is situated on the Mediterranean coast and Balearic islands. The Torrevieja plant is located in Alicante on the Mediterranean coast and was planned to provide water to both Alicante and its neighboring province, Murcia. The design and build contract was awarded to Spanish company Acciona Agua and construction commenced in 2007 (Acciona, 2016). Initially, the plant was expected to be operational by 2009 but this date was not met (DWR, 2015). A revised completion date of 2013 was agreed but this completion date was also missed (Gamm, 2012).

With a production capacity of $240 \mathrm{ML} / \mathrm{d}$, the Torrevieja facility is the biggest desalination plant in Europe and the second largest in the world to use reverse osmosis technology (Acciona, 2016). The plant was intended to increase the availability of desalinated water along the Mediterranean coast by over $50 \%$ in response to the booming tourist industry which required coastal development and as a new source of supply for agriculture (Cala, 2013). After considerable delay and controversy, the plant was completed in 2015, at a total construction cost of over US\$400 million, but remained idle until 2017. In 2018 was operating at around $60 \%$ capacity, and the central government announced its intention to increase total capacity to 360 ML/d (Freyberg, 2018; Leader, 2018).

The plant's development was subject to major delays throughout its construction, consistently missing completion targets. These delays were largely due to political conflict between regional and national governments. Water is a state-owned asset under Spain's 1985 Water Law and this legislation has since been extended specifically to include desalinated water (O'Neill Ocasio, 2015). There have been conflicts of jurisdiction between the national government and the regional government, which controls Torrevieja's town council (DWR, 2015), for example, a refusal by the regional government to grant environmental permits which was not resolved for more than two years (Mallet and Barr, 2011).

The Torrevieja desalination plant is part of the AGUA Program, which signified a change in water policy direction after the election of the Zapatero government in 2004. The plan was developed and implemented by Aguas de las Cuencas Mediterráneas (Acuamed), a nationally owned company (March, 2015). The 
AGUA Program has been responsible for the massive increase in large-scale desalination projects along the Mediterranean coast (March 2015). The AGUA Program was implemented in 2005 through a modification of the 2001 National Hydrological Plan, which had included plans for construction of the Ebro Aqueduct to transfer water from the North of Spain to the South (Loftus and March, 2016; Swyngedouw, 2015). More recently, desalination has been presented as a means of improving adaptation and resilience to climate change in south-eastern Spain (Morote et al., 2019).

The majority of the Torrevieja desalination project has been financed by Acuamed through the Ministry of Agriculture, Food and the Environment. The project initially received $€ 55$ million (US\$61 million) from European Union regional development funds, which was withdrawn following ongoing delays to construction. In 2016 the Torrevieja plant formed part of criminal investigations into cost over-runs in the awarding of contracts by Acuamed (Gallero, 2017).

The water produced by the desalination plant was planned to be split equally between agricultural irrigation and domestic consumption (TPF, 2016). However, with increased water prices it is unlikely that farmers would be able to afford the desalinated water reserved for them, and problems with construction of associated pipelines further delayed agricultural use as intended (March et al., 2014). Spanish agriculture is heavily reliant on desalinated water, using $80 \%$ of the country's desalinated water. The privately run energy sector doubled electricity prices between 2004 and 2013, driving up the costs of agriculture. If the heavily subsidized, publicly owned, water industry increases its prices, then a substantial amount of the country's agriculture would consequently become economically unviable (Cala, 2013). Optimizing water pricing during both normal and drought periods could increase the viability of desalination as part of a mixed supply strategy, including transfers and water reuse (Luque and Sirgado, 2019).

\section{England: The Beckton Desalination Plant}

The Beckton desalination plant, known as the Thames Gateway Water Treatment Works, was built to improve the resilience of London's water supply. Construction began in 2010 and was completed in 2011 but the plant has never been fully operated. The plant was initially planned in response to low reservoir levels in the south-east of England following two dry winters in a row, from 2004 to 2006, and has since been 
characterized as a 'resilience measure' to provide emergency supplies in the event of a serious drought (Marsh, 2007).

Water privatization was undertaken in England in 1989 (Walker, 2011). Thames Water is the company responsible for providing water services to London and the Thames Valley. The Beckton plant has a production capacity of 150 (ML/d) (Acciona, 2016). Unlike the other case study plants, the Beckton facility is not a seawater desalination plant but a brackish water desalination plant. It was constructed on behalf of Thames Water by a consortium of Interserve, Atkins Water and Acciona Agua. The plant cost $£ 250$ million (US\$367 million) to construct (Green Alliance, 2015). It is powered by renewable energy under a $£ 200$ million (US\$294 million) 20-year agreement with 2OC (2OC, 2013). A Combined Heat and intelligent Power (CHiP) plant supplies energy from waste fats oils and greases (FOGs).

The Beckton desalination plant was constructed amidst much controversy. The London mayor at the time of the first proposal, Ken Livingstone (Labour Party), was firmly opposed as were the Green Party members of the Greater London Assembly (BBC, 2006). Initially, the plant was denied planning permission on environmental grounds. Despite this, the plan for the plant won the GWI Sustainability Award in 2009 (Acciona, 2016). When Boris Johnson (Conservative Party) succeeded Ken Livingstone as Mayor of London in May 2008, he withdrew the objections to the desalination plant in his first week in office (Thames Water, 2008). Thames Water was urged by opponents of the desalination plant to concentrate on options with less environmental impact such as water recycling and reducing leakage (Bell, 2015).

The key justification for the development of the Beckton desalination plant was to provide resilience of water resources in the face of increasing climatic uncertainty. The operating agreement with the Environment Agency, which regulates water abstractions in England, requires that a drought event is declared and the river flows are below a specified level $(3,000 \mathrm{Ml} / \mathrm{d}$ or less for 10 consecutive days at Teddington Weir) (Thames Water, 2013). So far the plant has proved to be an unnecessary measure as the water system has remained in a non-failure state.

\section{Discussion}


While the Charles E. Meyer plant shows that idle desalination projects are not a new phenomenon, the other case studies also demonstrate continued underutilization of desalination capacity for domestic supply. The Beckton, Torrevieja and Kurnell plants are three high profile desalination projects developed during the last decade that remained idle for several years after they were completed (March, 2015). The main characteristics of all four idle desalination cases are summarized in Table 1.

Table 1. Comparing international cases of inactive desalination plants

\begin{tabular}{|c|c|c|c|c|}
\hline Location & $\begin{array}{l}\text { Santa Barbara, } \\
\text { California, USA }\end{array}$ & $\begin{array}{l}\text { Sydney, New South } \\
\text { Wales, Australia }\end{array}$ & $\begin{array}{l}\text { Torrevieja, Alicante, } \\
\text { Spain }\end{array}$ & $\begin{array}{l}\text { London, England, } \\
\text { UK }\end{array}$ \\
\hline Facility name & $\begin{array}{l}\text { Charles E. Meyer } \\
\text { desalination plant }{ }^{\mathrm{a}}\end{array}$ & Kurnell desalination plant ${ }^{\mathrm{a}}$ & $\begin{array}{l}\text { Torrevieja } \\
\text { desalination plant }^{v}\end{array}$ & $\begin{array}{lr}\text { Thames } & \text { Gateway } \\
\text { Water } & \text { Treatment } \\
\text { Works }^{v} & \end{array}$ \\
\hline $\begin{array}{l}\text { Technology } \\
\text { Capacity } \\
\text { (ML/d) }\end{array}$ & $\begin{array}{l}\text { Sea Water Reverse } \\
\text { Osmosis }^{\mathrm{b}} \\
\begin{array}{l}\text { Original plant } \\
\text { (scalable to } 35)^{\mathrm{c}}\end{array} \\
\text { Reactivation } 10\end{array}$ & $\begin{array}{l}\text { Sea Water Reverse } \\
\text { Osmosis }^{\mathrm{g}} \\
250(\text { scalable to } 500)^{\mathrm{d}}\end{array}$ & $\begin{array}{l}\text { Sea Water Reverse } \\
\text { Osmosis }^{\text {b }} \\
240^{\mathrm{v}}\end{array}$ & $\begin{array}{l}\text { Brackish Water } \\
\text { Reverse Osmosis } \\
150^{\mathrm{b}}\end{array}$ \\
\hline Ownership & $\begin{array}{l}\text { City of Santa } \\
\text { Barbara }^{\text {a }}\end{array}$ & $\begin{array}{l}\text { Sydney Desalination Plant } \\
\text { Pty Ltd. a Sydney Water } \\
\text { Company: leased to the } \\
\text { Ontario Teachers' Pension } \\
\text { Plan Board and Hastings } \\
\text { Funds Management Ltd. } \\
\text { in } 2012^{\text {d }}\end{array}$ & Acuamed $^{\mathrm{w}}$ & $\begin{array}{l}\text { Thames Water } \\
\text { Utilities Ltd. }{ }^{\mathrm{k}}\end{array}$ \\
\hline Contract period & 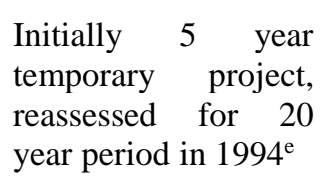 & $\begin{array}{l}50 \text { years }^{\mathrm{f}}, \text { current lease } 20 \\
\text { years }^{\mathrm{g}}\end{array}$ & 15 years $^{w}$ & $\mathrm{n} / \mathrm{a}$ \\
\hline Operator & $\begin{array}{l}\text { Ionics, Inc. (now } \\
\mathrm{GE})^{\mathrm{a}}\end{array}$ & $\begin{array}{l}\text { Blue Water: Veolia Water } \\
\text { and John Holland joint } \\
\text { venture }^{\text {h }}\end{array}$ & Acciona Aguab & Acciona Agua ${ }^{\mathrm{b}}$ \\
\hline Construction & $1991-1992^{\mathrm{i}}$ & $2007-2010^{\mathrm{d}}$ & $2007-2013^{j}$ & $2008-2010^{\mathrm{k}}$ \\
\hline Capital cost & $\begin{array}{l}\text { Original plant US\$34 } \\
\text { million }^{1} \\
\text { Reactivation } \\
\text { million }\end{array}$ & US\$1.8 billion ${ }^{\mathrm{d}}$ & US\$400 million ${ }^{1}$ & US\$367 million ${ }^{\mathrm{x}}$ \\
\hline $\begin{array}{l}\text { Finance } \\
\text { provider }\end{array}$ & $\begin{array}{l}\text { Ionics, Inc. then } \\
\text { bought back by City } \\
\text { of Santa Barbara and } \\
2 \text { local water } \\
\text { agencies over } 5 \\
\text { years }^{\mathrm{a}}\end{array}$ & $\begin{array}{l}\text { New South Wales } \\
\text { Treasury Corporation } \\
\text { (part of the NSW } \\
\text { government) }\end{array}$ & $\begin{array}{l}\text { Acuamed and EU } \\
\text { grant }^{\mathrm{m}}\end{array}$. & Thames Waterk \\
\hline
\end{tabular}




\begin{tabular}{|c|c|c|c|c|}
\hline Location & $\begin{array}{l}\text { Santa Barbara, } \\
\text { California, USA }\end{array}$ & $\begin{array}{l}\text { Sydney, New South } \\
\text { Wales, Australia }\end{array}$ & $\begin{array}{l}\text { Torrevieja, Alicante, } \\
\text { Spain }\end{array}$ & $\begin{array}{l}\text { London, England, } \\
\text { UK }\end{array}$ \\
\hline Awards & $\mathrm{n} / \mathrm{a}$ & $\begin{array}{l}\text { Desalination plant of the } \\
\text { year } 2011 \text { at the Global } \\
\text { Water Summit }^{\mathrm{n}}\end{array}$ & $\begin{array}{l}\text { Recognized by KPMG } \\
\text { as one of the World's } \\
\text { Top } 100 \quad \text { most } \\
\text { innovative structures } \\
\text { of the } 21 \text { st Century }\end{array}$ & $\begin{array}{l}\text { Winner of the } \\
\text { Sustainability Award } \\
-\quad \text { Global Water } \\
\text { Intelligence } 2009^{\mathrm{v}}\end{array}$ \\
\hline Energy & From grid & $\begin{array}{l}\text { Renewable: Capital Wind } \\
\text { Farm (via grid) }\end{array}$ & Not yet supplied ${ }^{\mathrm{q}, \mathrm{w}}$ & Renewable: $\mathrm{CHiP}^{\circ}$ \\
\hline Status 2019 & $\begin{array}{l}\text { Longterm standby } \\
\text { since } 1997 ; \\
\text { reactivation began in } \\
2015 \text { and water } \\
\text { supplied in 2017 }\end{array}$ & $\begin{array}{l}\text { Currently being } \\
\text { reactivated after being on } \\
\text { longterm standby since } \\
2012 ; \text { damaged by tornado } \\
\text { Dec } 2015^{\mathrm{d}}\end{array}$ & $\begin{array}{l}\text { Operating at } 60 \% \\
\text { capacity, with plans } \\
\text { for expansion }{ }^{\mathrm{q}}\end{array}$ & Longterm standby \\
\hline $\begin{array}{l}\text { Average rainfall } \\
(\mathrm{mm} / \mathrm{y})\end{array}$ & $493^{r}$ & $1164^{\mathrm{s}}$ & $284^{t}$ & $621^{\mathrm{t}}$ \\
\hline
\end{tabular}

a (Cooley and Ajami, 2012), b (March, 2015), c (IDE, 2015), d (Fuenfschilling and Truffer, 2016), e (City of Santa Barbara City Council, 1994), f (Radcliffe, 2015), g (El Saliby et al., 2009), h (Sydney Water, July 2010), i (Cooley et al., 2006), j (Gamm, 2012), k (Thames Water, 2008), 1 (O’Neill Ocasio, 2015), m (Mallet and Barr, 2011), n ("Kurnell Desalination Plant", 2016), o (2OC, 2013), p (Hamilton, 2015), q (Cala, 2013), r (US Climate Data, 2016), s (Australian Government, 2016), t (Climate-Data, 2016), u (Mekonnen and Hoekstra, 2011), v (Acciona, 2016), w (March et al., 2014), x (Green Alliance, 2015), y (Our History, 2016)

By creating an assumed limitless supply, desalination follows the logic of the twentieth century hydraulic paradigm and suggests that water security is best achieved through large-scale, capital intensive engineering solutions. A key factor undermining the sustainability of desalination is its role in intensifying the waterenergy nexus (March, 2015). Currently, only $0.02 \%$ of global desalination is powered by a renewable energy source (Reif and Alhalabi, 2015). The case study plants demonstrate that efforts are being made to address this issue. Both Beckton and Kurnell offset their high energy consumption with renewable energy. While gradual energy efficiency improvements and technological advances will further decrease the costs of desalination in the short to medium-term, growing expectations that ecological costs are fully incorporated in projects may mean that desalination plants become more expensive (March, 2015). Environmental protection was cited as a key reason for the high cost of the Kurnell desalination plant, and also for the expense of the Charles E. Meyer reactivation program.

As a supply-side response to drought and water scarcity, desalination maintains the basic structure and operating principles of centralized water infrastructure and the hydraulic paradigm (Saurí and Moral, 2001, Zeitoun et al., 2016). The widespread and rapid adoption of desalination technology is in part a product of the ease with which the technology fits within the existing socio-technical and institutional frameworks. In 
recent decades desalination has been presented as a better solution than dams and water transfers, which dominated the hydraulic paradigm in the $20^{\text {th }}$ century (Allan, 2005). In Spain, the proposed Ebro transfer project was abandoned by the newly elected Zapatero government in 2004 in favor of a complete overhaul to the national water plan which focused largely on desalination. In England desalination was seen to be more favourable than the Severn-Thames transfer project. In Santa Barbara reactivation of the local desalination plant has been chosen over transfers from northern California. This shows that water utilities and resource managers prefer to invest in 'climate-independent' technologies over traditional infrastructure options. Environmentalists generally advocate for local supplies to be developed rather than increased water transfers, due to the negative effects of transfers on ecosystems (NWC, 2008). However, the energy requirements and environmental impacts of desalination undermine its construction as a 'sustainable' alternative to large scale transfers.

In Sydney, desalination has become the first response to declining dam levels because of drought. The Kurnell plant was called into service for the first time in 2019 with dam levels at $60 \%$ capacity, before any restrictions on demand for water. Desalination as an early response to low rainfall undermines efforts to manage demand for water, which has been a central principle of integrated and sustainable urban water management. This is contrast to the operating conditions for the Beckton plant in London, which may only supply water after use restrictions have proved insufficient to maintain critical baseflows in the River Thames.

Desalination's claims to provide a climate-independent source of water are affirmed by its presence in the highly varied climates of the case studies. Whereas early expansion of desalination was in hot, dry climates, the case study plants include a stark diversity of hydrological and meteorological conditions (Jones et al., 2019). Annual average rainfall is $284 \mathrm{~mm}$ in Torrevieja, $493 \mathrm{~mm}$ in Santa Barbara, $621 \mathrm{~mm}$ in London and $1,163 \mathrm{~mm}$ in Sydney (Table 1).

As a drought response, annual average rainfall is not as important as inter-annual variability. Desalination is increasingly presented as the means to improve the resilience of cities to drought. This is the explicit rationale for the Beckton plant in London, and the Torrevieja plant has been shown to improve the climate 
resilience of South-Eastern Spain (Morote et al., 2019). Idle desalination plants fulfil the function of redundant capacity within the system, which can be brought into service during an extreme event. The high cost of desalination may therefore be traded off against the consequences of water scarcity and the risk of system failure during prolonged drought. This conventional engineering definition of resilience conforms to reductionist framings of water security, emphasizing quantification and financialization of risk management, to the detriment of integrative water security which addresses wider social, political and cultural factors (Holling, 1996; Zeitoun et al., 2016).

The certainty of supply with minimal disruption to existing social and cultural patterns of consumption that is provided by desalination make it an attractive option during a severe drought. Both the Charles E. Meyer and Kurnell plants were commissioned and built during extreme events, even though the drought ended before either plant was able to supply water. In Sydney the decision was taken before an election campaign, and in Santa Barbara it was confirmed by a referendum. Public and political support for desalination is heightened by experience of drought, which may undermine longer-term water management strategies and more integrated assessment of options under conditions of uncertainty (Turner et al., 2016).

Investment in desalination is not simply driven by a desire to climate-proof cities, but it also shows the rise of private finance as a factor shaping infrastructure decisions, an important shift from the classic hydraulic paradigm to its neo-hydraulic manifestation. Desalination plants are largely constructed by public-private consortia (March, 2015). Across the world 58\% of new desalination projects have been privately financed (March, 2015). This increase in multinational, private actors in water supply augmentation, evident in all four of the case study plants, reflects a wider shift in the political economy of water management (March, 2015). The Kurnell plant in particular emphasizes that desalination projects are not accountable to a single entity, being a government funded initiative, operated by a consortia of private companies, which is currently under a long-term private lease.

Both GE Water (now owner of Ionics), and IDE, the companies responsible for the original construction and reactivation of the Santa Barbara plant, are major international contractors. While Ionics was an American company, the reactivation contract being awarded to a subsidiary of Israeli desalination company IDE, shows 
the increasingly multinational nature of desalination projects. Alongside GE and IDE, Acciona Agua and Veolia are also amongst the largest engineering, procurement and construction contractors for desalination in the world (March, 2015). Spanish company Acciona Agua is responsible for two of the case study plants while Veolia in particular is noted to have high activity across the globe, having built $15 \%$ of the world's desalination capacity (March, 2015). This highlights how just a few multinational companies provide desalination knowledge and distribution, emphasizing the continued dominance of engineering expertise in neo-hydraulic water management (March et al., 2014).

Idle plants are 'stranded assets', requiring ongoing expenditure in addition to the 'sunk costs' of the original construction and capital outlay. The energy involved in maintaining a plant in stand-by mode contributes significant operating and maintenance costs for desalination plants, even when they are not producing drinking water. The investment in desalination infrastructure means that once constructed they are unlikely to be easily abandoned. The repeated efforts to include the idle Charles E. Meyer desalination plant into Santa Barbara's long-term water plan demonstrates this. The Santa Barbara plant highlights how 'futureproofing' can be used to justify expensive desalination plants which are not needed once construction is complete. Similarly, above average rainfall and gradual leakage reduction in London mean that the Beckton desalination plant has remained surplus to requirements since its construction.

\section{Conclusion}

The rapid rise of desalination in the first decade of the twenty-first century echoes the hydraulic paradigm of twentieth century water management. A key reason for the relative ease with which desalination has been integrated into existing water systems is that it fits with existing cultural expectations and patterns of relationships between cities, infrastructure and natural resources. The case studies of idle desalination plants demonstrate the persistence of centralized supply-side responses to water scarcity over less certain, decentralized and demand-side options. Neo-hydraulic approaches to water management continue the engineering-led, capital intensity of solutions to alleviate uncertainty in water resources, but with greater opportunities for secure returns on private capital investment than the state-led projects of the twentieth century. 
Analysis of under-utilized desalination capacity, represented by the four cases studies, provides an important balance to technologically optimistic accounts of desalination as the ultimate solution to global challenges of water insecurity. Desalination is an important option for water managers and has a role to play in reducing vulnerability to drought and climate change. However, as the cases show, desalination is an expensive means to improve the resilience of water infrastructure constructed under the hydraulic paradigm of the twentieth century. The neo-hydraulic logic of desalination as a reductionist water security measure also highlights the need for more robust, integrative decision-making for resilience. This includes consideration of social and cultural capacity to respond to drought and adapt to climate change, as well as the political and economic consequences of decisions, and recognition of the financial beneficiaries of desalination investment and contracts.

This paper has focused on desalination plants that were or remain idle for extended periods after construction. Under-utilization of desalination capacity is also evident in plants that are operational at significantly below their designed output. Accounts of the growth of desalination typically report installed rather than operational capacity (see for example Jones et al., 2019). More comprehensive, quantitative analysis of the operational status of desalination plants world-wide is needed to assess the scale of overcapacity and over-investment in desalination.

Idle desalination plants demonstrate the vulnerability of technology-led water security that characterises the neo-hydraulic approach to water management. The promise of certainty of supply in the face of uncertain hydrological conditions is attractive to political decision-makers, and it also serves the interests of private firms and international finance. Desalination is an expensive and energy intensive method of supplying clean water. It remains expensive even when the plants are idle. While private investors and technology providers benefit from contracts to build and maintain plants, even if they aren't operated, water users and governments pay the cost through water bills, grants and subsidies. While the evidence of the transition to an integrated water management paradigm grows, idle desalination plants provide a warning of the consequences of the neo-hydraulic convergence of local political imperatives to provide water security through certainty and the global interests of investors in and suppliers of capital intensive infrastructure. 


\section{References}

2OC. (2013, June 4). $£ 200 \mathrm{~m}$ power deal and multi-million investment for 2OC. Retrieved from http://www.2oc.co.uk/announcement/200m-power-deal-and-multi-million-investment-for-2oc/

AAP. (2008, February 9). More of NSW moves out of drought - Water - Specials. Sydney Morning Herald. Retrieved from http://www.smh.com.au/news/water/more-of-nsw-moves-out-ofdrought/2008/02/09/1202234214539.html

ABC. (2017, March 19). Victoria's desalination plant finally delivers as Government places order for more water. Retrieved on 4 December 2018, from https://www.abc.net.au/news/2017-03-19/victoria-desalinationplant-finally-delivers-water/8367554.

Acciona. (2016). Acciona Agua: Your partner in the water cycle. Retrieved from http://www.spainbusiness.com/icex/cma/contentTypes/common/records/mostrarDocumento/?doc=4745532

Allan, J. A. (2005). Water in the Environment / Socio-Economic Development Discourse: Sustainability, Changing Management Paradigms and Policy Responses in a Global System. Government and Opposition. 40(2), 181-199.

Andrew, S. (2007). Water and cities - overcoming inertia and achieving a sustainable future, in: Cities of the Future: Towards Integrated Sustainable Water and Landscape Management. Proceedings of an International Workshop Held July 12-14, 2006 in Wingspread Conference Center, Racine, WI. London: IWA Publishing, pp. 18-31.

Australian Government. (2016). Bureau of Meteorology: Climate statistics for Australian locations. Bom.gov.au. Retrieved from http://www.bom.gov.au/climate/averages/tables/cw_066062.shtml

Bahkri, A. (2012). Integrated Urban Water Management. Stokholm: Global Water Partnership.

Bakker, K. (2010). Privatizing Water. Ithaca and London: Cornell University Press.

BBC. (2006, May 23). Inquiry on salt water plant plan. BBC News website. Retrieved from http://news.bbc.co.uk/1/hi/england/london/5004912.stm

Bell, S. (2015). Renegotiating urban water. Progress in Planning, 96, 1-28.

Bell, S. (2018). Urban Water Sustainability: Constructing Cities for People and Nature. Abingdon: Routledge.

Bennett, A. (2015). Developments in desalination and water reuse. Filtration + Separation, 52(4), 28-33.

Biswas, A.K. (2004). Integrated Water Resources Management: A Reassessment. Water International, 29, 248-256.

Brown, R.R., Keath, N., Wong, T.H.F., 2009. Urban water management in cities: historical, current and future regimes. Water Science \& Technology, 59, 847-855.

Cala, A. (2013, October 9). Spain's desalination ambitions unravel. The New York Times. Retrieved from http://nytimes.com

Chye, K. T. (2013). Seawater desalination: a promise for China's future? Water and Wastwater International, 28 (4), available from: http://www.waterworld.com/articles/wwi/print/volume-28/issue4/international-show-previews/ida-world-congress-2013-tianjin-china/seawater-desalination-a-promise-forchina-s.html, accessed 2 April 2017. 
City of Santa Barbara City Council. (1994). LTWSP: Desalination EIA. Retrieved from ftp://swrcb2a.waterboards.ca.gov/pub/rwqcb3/katied/OceanPlan/LTWSP\%20EIR\%20Desal\%205-24-94.pdf

City of Santa Barbara. (2019) Charles E. Meyer Desalination Plant. Retrieved from https://www.santabarbaraca.gov/gov/depts/pw/resources/system/sources/desalination/default.asp?utm_source =PublicWorks\&utm_medium=Desal\&utm_campaign=QuickLinks

Climate-Data. (2016). Climate data for cities worldwide. climate-data.org. Retrieved from http://en.climatedata.org

Cockburn, P. (2019). Sydney's desalination plant is turned on - so what does that mean? ABC News. Retrieved from https://www.abc.net.au/news/2019-01-27/sydney-desalination-plant-turned-on-so-how-doesit-work/10753334

Cook, C., and Bakker, K. (2012). Water security: debating and emerging paradigm. Global Environmental Change, 22, 94-102.

Cooley, H., Gleick, P. H., and Wolff, G. (2006). Desalination, with a Grain of Salt: a California perspective. Pacific Institute, Oakland, California.

Cooley, H., and Ajami, N. (2012). Key Issues for Seawater Desalination in California: Cost and Financing. Pacific Institute, Oakland, California, 48.

Danoun, R. (2007). Desalination Plants: Potential impacts of brine discharge on marine life. University of Sydney.

Dickie, P. (2007). Making Water. Desalination: option or distraction for a thirsty world. WWF's Global Freshwater Program.

Dillon, P. (2011). Water security for Adelaide. In R. Q. Grafton and K. Hussey (Eds.), Water resources planning and management (pp. 505 - 526). Cambridge University Press.

Dolnicar, S. and Hurlimann, A. (2010) Desalinated Versus Recycled Water - What Does the Public Think? In I. C. Escobar and A. Schäfer (Eds.), Sustainability Science and Engineering, 2, Sustainable water for the the future: water recycling versus desalination (pp. 375-388). Elsevier.

DWR. (2015, February 17). Delayed Torrevieja plant pays penalty. Desalination.biz. Retrieved from http://www.desalination.biz/news/news_story.asp?id=7925

El Saliby, I., Okour, Y., Shon, H. K., Kandasamy, J., and Kim, I. S. (2009). Desalination plants in Australia, review and facts. Desalination, 247(1), 1-14.

EU Committee on Petitions. (2008). Petition 0823/2007 by Mr Santiago López Segovia (Spanish), on an EUfunded project for the construction of a desalination plant in Torrevieja (Alicante). European Parliament. Retrieved from http://www.europarl.europa.eu/meetdocs/2004_2009/documents/cm/729/729482/729482en.pdf

Fletcher, T. D., Shuster, W., Hunt, W. F., Ashley, R., Butler, D., Arthur, S., Trowsdale, S., Barraud, S., Semadeni-Davies, A., Bertrand-Krajewski, J., Mikkelsen, P. S., Rivard, G., Uhl, M., Dagenais, D., and Viklander, M. (2014). SUDS, LID, BMPs, WSUD and more - The evolution and application of terminology surrounding urban drainage. Urban Water Journal, 12(7), 525-542

Freyberg, T. (2018). Torrevieja desalination plant production could be trebled in Spain. WWI. Retrieved from https://www.waterworld.com/articles/wwi/2018/03/torrevieja-desalination-plant-capacity-could-be-trebledin-spain.html 
Fuenfschilling, L., and Truffer, B. (2016). The interplay of institutions, actors and technologies in sociotechnical systems-An analysis of transformations in the Australian urban water sector. Technological Forecasting and Social Change, 103, 298-312.

Gallero, M. (2017). Un año del escándalo Acuamed. ABC España. Retrieved from https://www.abc.es/espana/abci-escandalo-acuamed-201701180214_noticia.html

Gamm, J. (2012, November 22). Torrevieja desalination plant makes Best 100 Most Innovative. RTN. Retrieved http://www.rtnnewsgroup.com/index.php?option=com_k2andview=itemandid=39718:torreviejadesalination-plant-makes-best-100-most-innovativeandItemid=235

Gasson, C. (2015, November 12) Desalination market forecast [Webinar]. In DesalData.

Green Alliance. (2015). Cutting the cost of water: The case for improving water efficiency in the UK. London: Green Alliance.

Hamilton, M. (2015, July 22). Santa Barbara to spend \$55 million on desalination plant as drought 'last resort'. The LA Times. Retrieved from http://www.latimes.com/local/lanow/la-me-ln-santa-barbarareactivating-desalination-plant-20150721-story.html

Hashim, A., and Hajjaj, M. (2005). Impact of desalination plants fluid effluents on the integrity of seawater, with the Arabian Gulf in perspective. Desalination, 182(1), 373-393.

Hoepner, T. (1999). A procedure for environmental impact assessments (EIA) for seawater desalination plants. Desalination, 124(1), 1-12.

Holling, C. S. (1996). Engineering resilience versus ecological resilience. P. Schulze (ed), Engineering Within Ecological Constraints, Washington DC, National Academy Press, pp. 31-44.

Hundley, N. (1992). The Great Thirst. Berkeley: University of California Press.

IDA. (2008). Desalination in 2008. Global Market Snapshot. $21^{\text {st }}$ GWI/ International Desalination Assoication Worldwide Desalting Inventory. Revtrieved from http://idadesal.org/wpcontent/uploads/2008/10/2008ida-desalination-snapshot_october-2008.pdf

IDA. (2015). Desalination by numbers. International Desalination Association. Retrieved from http://idadesal.org/desalination-101/desalination-by-the-numbers/.

IDA. (2016). Desalination Yearbook 2016-2017. Oxford: International Desalination Association.

IDE. (2015). Charles E. Meyer Desalination Plant Reactivation, California, United States of America - IDE Technologies. Retrieved from http://www.ide-tech.com/blog/publication/charles-e-meyer-desalination-plantreactivation-california-united-states-america/

IPART. (2011, June) Review of prices for Sydney Desalination Plant Pty Limited's water supply services for the period to 30 June 2017. Retrieved from http://www.staging.ipart.nsw.gov.au/files/43da8133-ec17-4c9cb870-9f2400b80f90/Issues_Paper_-

Review of prices for Sydney Desalination Plant Pty Limiteds water supply services - June 2011.pdf

IPART. (2011, December) Prices for Sydney Desalination Plant Pty Limited's Water Supply Services. Retrieved from http://www.ipart.nsw.gov.au/files/sharedassets/website/trimholdingbay/determination__prices_for_sydney_desalination_plant_pty_limiteds_water_supply_services_-_december_2011.pdf

Jones, E., Qadir, M., van Vliet, M. T. H., Smakhtin, V., and Kang, S. (2019). The state of desalination and brine production: A global outlook. Science of the Total Environment, 657, 1343-1356. 
Kjeldsen, T. R., and Rosbjerg, D. (2004). Choice of reliability, resilience and vulnerability estimators for risk assessments of water resources systems/Choix d'estimateurs de fiabilité, de résilience et de vulnérabilité pour les analyses de risque de systèmes de ressources en eau. Hydrological sciences journal, 49(5).

Kurnell Desalination Plant. (2016). Water Technology. Retrieved from http://www.watertechnology.net/projects/kurnell-desalination/

Lattemann, S., Kennedy, M. D., Schippers, J. C., and Amy, G. (2010). Global desalination situation. In I. C. Escobar and A. Schäfer (Eds.), Sustainability Science and Engineering, 2, Sustainable water for the the future: water recycling versus desalination (pp. 7-40). Elsevier.

Lattemann, S., and Höpner, T. (2008). Environmental impact and impact assessment of seawater desalination. Desalination, 220(1), 1-15.

Leader (2018). Torrevieja desalination plant to triple production. Le@der. Retrieved from http://www.theleader.info/2018/03/28/torrevieja-desalination-plant-triple-production/\#_.

Loftus, A., and March, H. (2016). Finacializing Desalination: Rethinking the Returns of Big Infrastructure. International Journal of Urban and Regional Research. 40(1), 46-61.

Luque, J. A., and Sirgado, L. J. (2019) Water demand related to availability and price in an irrigation district in the Segura Basin. International Journal of Water Resources Development. 35(1), 160-174.

Mallet, V., and Barr, C. (2011, April 26). Spain's desalination dreams run dry. Financial Times. Retrieved from http://www.ft.com/cms/s/0/0cb6af3a-7024-11e0-bea7-00144feabdc0.html\#axzz3zZisVODW

March, H. (2015). The politics, geography, and economics of desalination: A critical review. Wiley Interdisciplinary Reviews: Water, 2(3), 231-243.

March, H., Saurí, D., and Rico-Amorós, A. M. (2014). The end of scarcity? Water desalination as the new cornucopia for Mediterranean Spain. Journal of Hydrology, 519, 2642-2651.

Marsh, T. (2007). The 2005-2006 drought in southern Britain. Weather, 62(7), 191-196.

Mekonnen, M.M. and Hoekstra, A.Y. (2011). National Water Footprint Accounts: the green, blue and grey water footprint of production and consumption, Value of Water Research Report Series No. 50, UNESCOIHE, Delft, The Netherlands.

Miller, S., Shemer, H., and Semiat, R. (2015). Energy and environmental issues in desalination. Desalination, 366, 2-8.

Mitchell, V. (2006). Applying Integrated Urban Water Management Concepts: A Review of Australian Experience. Environmental Management. 37, 589-605.

Morote, A., Olcina, J., and Hernandez, M. (2019) The Use of Non-Conventional Water Resources as a Means of Adaptation to Drought and Climate Change in Semi-Arid Regions: South-Eastern Spain. Water, $11,93$.

National Water Commission (NWC). (2008). Emerging Trends in Desalination: A Review. November 2008. Waterlines Report Series No 9, October 2008.

Novotny, V., Ahern, J., Brown, P. (2010). Water Centric Sustainable Communities. Hoboken: John Wiley and Sons.

Onishi, N. (2010, July 10). Arid Australia sips seawater, but at a cost. The New York Times. Retrieved from http://nytimes.com 
O’Neill Ocasio, K. M. (2015). Feeling Salty: Regulating Desalination Plants in the United States and Spain. Cornell Int'l LJ, 48, 451.

Palomar, P., and Losada, I. J. (2010). Desalination in Spain: recent developments and recommendations. Desalination, 255(1), 97-106.

Radcliffe, J. C. (2015). Water recycling in Australia-during and after the drought. Environmental Science: Water Research and Technology, 1(5), 554-562.

Reif, J. H., and Alhalabi, W. (2015). Solar-thermal powered desalination: Its significant challenges and potential. Renewable and Sustainable Energy Reviews, 48, 152-165.

Roberts, D. A., Johnston, E. L., and Knott, N. A. (2010). Impacts of desalination plant discharges on the marine environment: A critical review of published studies. Water Research, 44(18), 5117-5128.

Saurí, D., and del Moral, L. (2001). Recent developments in Spanish water policy. Alternatives and conflicts at the end of the hydraulic age. Geoforum, 32(3), 351-362.

SEQ Water (2018). Desalination. Retrieved 4 December 2018, from https://www.seqwater.com.au/watersupply/water-treatment/desalination.

Shiklomanov I. (1993). World freshwater resources, Chapter 2 in Gleik P. (ed) Water in Crisis. Oxford and New York: Oxford University Press.

Sofoulis Z. (2005) Big Water, Everyday Water: A Sociotechnical Perspective Continuum: Journal of Media and Cultural Studies 19(4) 445-463.

Stanford, B. D., Leising, J. F., Bond, R. G., and Snyder, S. A. (2010). Inland desalination: current practices, environmental implications, and case studies in Las Vegas, NV. In I. C. Escobar and A. Schäfer (Eds.), Sustainability Science and Engineering, 2, Sustainable water for the the future: water recycling versus desalination (pp. 327-350). Elsevier.

Sun, Y. (2016) China's Massive Effort To Purify Seawater is Drying Up. MIT Technology Review, July 11 2016, available from https://www.technologyreview.com/s/601861/chinas-massive-effort-to-purifyseawater-is-drying-up/, accessed 2 April 2017.

Swyngedouw, E. (2015) Liquid Power. Cambridge and London: MIT Press.

Sydney Desal. (2014). Desalination plants: The insurance policy we have to have. Utility Magazine. Retrieved from http://www.sydneydesal.com.au/media/1137/00027112.pdf

Sydney Desal. (2018) Regulatory framework. Retrieved on 4 December 2018, from http://www.sydneydesal.com.au/regulatory-framework/.

Sydney Water. (2010, July). Sydney's Desalination Project. The Institution of Engineers Australia. Retrieved from https://www.engineersaustralia.org.au

Thames Water Utilities Ltd. (2008). Annual Report and Financial Statements for the year ended 31 March 2008. Retrieved from https://www.thameswater.co.uk/tw/common/downloads/aboutus-financial/2008-twulannual-report-full-year-statements.pdf

Thames Water Utilities Ltd. (2013). Final Drought Plan. Retrieved from https://corporate.thameswater.co.uk/about-us/our-strategies-and-plans/our-drought-plan

TPF. (2016). Torrevieja Desalination Plant | TPF. Tpf.eu. Retrieved from http://tpf.eu/projects/torreviejadesalination-plant/ 
Trembath, M. (2015, April 30). Call to close Kurnell desalination plant. St George and Sutherland Shire Leader. Retrieved 24 March 2016, from http://www.theleader.com.au/story/3045382/call-to-close-kurnelldesalination-plant/

Troy, P. (2011). The urban water challenge in Australian cities. In R. Q. Grafton and K. Hussey (Eds.), Water resources planning and management (pp. 463 - 482). Cambridge University Press.

Turner, A., White S., Chong, J., Dickinson M., Cooley, H. and Donnelley K. (2016). Managing Drought: Learning from Australia. Oakland: Pacific Institute, Retrieved 12 April 2017 from http://pacinst.org/publication/managing-drought-learning-from-australia/

United Nations Department for Economic and Social Affairs (2018). Sustainable Development Goal 6. Retrieved 4 December 2018, from https://sustainabledevelopment.un.org/sdg6.

United Nations Sustainable Development (1992). Agenda 21. Retrieved 4 December 2018, from https://sustainabledevelopment.un.org/content/documents/Agenda21.pdf

US Climate Data. (2016). Climate Santa Barbara - California. usclimatedata.com. Retrieved 4 December 2018, from http://www.usclimatedata.com/climate/santa-barbara/california/united-states/usca1017

Walker, G. (2011). Water soft path thinking in other developed economies: Part A, England. In Brooks, D. B., Brandes, O. M., and Gurman, S. (Eds.), Making the most of the water we have: the soft path approach to water management (pp. 206-210). London: Earthscan.

Water Resources Division, Public Works Department. (2015, June 16). Council Agenda Report: Award Of Contract For The Charles E. Meyer Desalination Plant - Final Design Phase. Retrieved from http://santabarbara.granicus.com/DocumentViewer.php?file=santabarbara_4a376d2afb53d767f9a6af728b85 1bd7.pdfandview $=1$

Wilf, M., Awerbuch, L., Bartels, C., Mickley, M., Pearce, G., and Voutchkov, N. (2007). The guidebook to membrane desalination technology. Balaban: Desalination Publications.

Worster, D. (1985). Rivers of Empire. New York: Pantheon Books.

Younos, T. (2005). Environmental issues of desalination. Journal of Contemporary Water Research and Education, 132(1), 11-18.

Zeitoun, M., Lankford, B., Krueger, T., Forsyth, T., Carter, R., Hoekstra, A. Y., Taylor, R., Varis, O., Cleaver, F., Boelens, R., Swatuk, L., Tickner, D., Scott, C. A., Murimachi, N., and Matthews, N. (2016).

Reductionist and integrative research approaches to complex water security challenges. Global Environmental Change, 39, 143-154.

Zheng, X., Chen, D., and Zhang, Z. (2014). Seawater desalination in China: retrospect and prospect. Chemical Engineering Journal, 242, 404-413. 